\title{
The phylogenetic position of Anacanthorus (Monogenea, Dactylogyridae) parasitizing Brazilian serrasalmids (Characiformes)
}

\author{
Juliana Moreira ${ }^{1}$, José L. Luque ${ }^{1,2}$, and Andrea Šimková ${ }^{3, *}$ \\ ${ }^{1}$ Curso de Pós-Graduação em Biologia Animal da Universidade Federal Rural do Rio de Janeiro, BR 465, Km 7, Caixa Postal 74.540, \\ 23890-000, Seropédica, RJ, Brazil \\ 2 Departamento de Parasitologia Animal, Universidade Federal Rural do Rio de Janeiro, Caixa Postal 74.540, 23851-970, Seropédica, RJ, \\ Brazil \\ ${ }^{3}$ Department of Botany and Zoology, Faculty of Science, Masaryk University, Kotlářská 2, Brno, 611 37, Czech Republic
}

Received 28 March 2019, Accepted 10 July 2019, Published online 23 July 2019

\begin{abstract}
Anacanthorus (Anacanthorinae) is one of the most speciose and common genera of neotropical monogeneans, yet there are still many gaps in our knowledge concerning their diversity and phylogeny. We performed phylogenetic analyses of molecular sequences in order to investigate the phylogenetic position within the Dactylogyridae of Anacanthorus spp. infesting serrasalmids from two Brazilian river basins. Sequences of partial 28S rDNA obtained for nine species of Anacanthorus and Mymarothecium viatorum parasitizing serrasalmids and the published sequences of other members of the Dactylogyridae were included in the phylogenetic reconstruction. Phylogenetic analyses supported the monophyly of anacanthorine monogeneans. The Anacanthorinae (represented in this study by Anacanthorus spp.) formed a monophyletic group included in a large clade together with a group of solely freshwater Ancyrocephalinae and species of the Ancylodiscoidinae. Mymarothecium viatorum (Ancyrocephalinae) was placed within the clade of freshwater Ancyrocephalinae. The phylogenetic analyses indicated that the relationships among species of Anacanthorus reflect those of their serrasalmid hosts: the first subgroup includes a species specific to hosts assigned to Piaractus, a member of the "pacus" lineage; the second subgroup includes a species parasitizing the "Myleus-like pacus" lineage; and the third subgroup includes species parasitizing the lineage of the "true piranhas". We suggest that Anacanthorus and their serrasalmid hosts can be considered a useful model to assess host-parasite biogeography and coevolution in the neotropics. However, future studies focusing on a wider spectrum of host species and their specific Anacanthorus spp. are needed in order to investigate coevolution in this highly diversified system.
\end{abstract}

Key words: Anacanthorus, Dactylogyridae, Serrasalmidae, Neotropical region, 28S rDNA, Molecular phylogeny.

Résumé - La position phylogénétique d'Anacanthorus (Monogenea, Dactylogyridae) parasitant les Serrasalmidés brésiliens (Characiformes). Anacanthorus (Anacanthorinae) est parmi les genres les plus riches en espèces et les plus communs parmi les monogènes néotropicaux. Cependant, nos connaissances sur sa diversité et sa phylogénie sont encore lacunaires. Nous avons effectué des analyses phylogénétiques de séquences moléculaires afin d'étudier la position phylogénétique au sein des Dactylogyridae d'Anacanthorus spp. infestant des Serrasalmidés de deux bassins fluviaux brésiliens. Les séquences d'ADNr $28 \mathrm{~S}$ partiel obtenues pour 9 espèces d'Anacanthorus et Mymarothecium viatorum parasitant les Serrasalmidés et les séquences publiées d'autres membres des Dactylogyridae ont été incluses dans la reconstruction phylogénétique. Les analyses phylogénétiques ont confirmé la monophylie des Anacanthorinae. Les Anacanthorinae (représentés dans cette étude par Anacanthorus spp.) forment un groupe monophylétique inclus dans un grand clade avec un groupe d'Ancyrocephalinae uniquement d'eau douce et d'espèces d'Ancylodiscoidinae. Mymarothecium viatorum (Ancyrocephalinae) a été placé dans le clade des Ancyrocephalinae d'eau douce. Les analyses phylogénétiques indiquent que les relations entre les espèces d'Anacanthorus reflètent celles de leurs hôtes Serrasalmidés : le premier sous-groupe comprend une espèce spécifique aux hôtes attribués à Piaractus, un membre de la lignée «pacus »; le deuxième sous-groupe comprend une espèce parasitant la lignée «pacus proche de Myleus »; et le troisième sous-groupe comprend les espèces parasitant la lignée des «vrais piranhas ». Nous pensons qu'Anacanthorus et ses hôtes Serrasalmidés peuvent être considérés comme un modèle utile pour évaluer la

*Corresponding author: simkova@sci.muni.cz

This is an Open Access article distributed under the terms of the Creative Commons Attribution License (http://creativecommons.org/licenses/by/4.0), which permits unrestricted use, distribution, and reproduction in any medium, provided the original work is properly cited. 
biogéographie hôte-parasite et la coévolution dans les régions néotropicales. Cependant, de futures études portant sur un spectre plus large d'espèces hôtes et de leurs espèces spécifiques d'Anacanthorus spp. sont nécessaires pour étudier la coévolution dans ce système hautement diversifié.

\section{Introduction}

Due to their direct life cycle, morphological adaptation, and high host specificity, gill monogeneans of fish are commonly studied parasites in the context of coevolution and biogeography of host-parasite systems [37, 58, 60]. The reconstruction of the evolutionary history of parasites and the investigation of their origin is the first step in coevolutionary studies. However, despite the enormous diversity of both freshwater fish and their monogenetic fauna (e.g., [1, 8, 14, 46]), coevolutionary studies of fish and their monogenean parasites from the Neotropical Region are still limited.

Anacanthorus Mizelle and Price, 1965 is one of the most diverse monogenean genera living on fish in the Neotropical Region. Of the 15 genera parasitizing serrasalmids, Anacanthorus currently comprises 75 nominal species, which are distributed on species of Bryconidae (15 species), Characidae (22), and Serrasalmidae (38) [9, 33, 42]. However, undescribed species of Anacanthorus have also recently been recorded on species of Erythrinidae [19, 20]. Anacanthorus belong to Anacanthorinae Price, 1967, which is restricted to the Neotropical Region, and at present this group accommodates only Anacanthorus and Anacanthoroides Kritsky \& Thatcher, 1974, the latter being represented by only two species recorded on the Prochilodontidae.

The freshwater fish of the Serrasalmidae, representing the most common host group for Anacanthorus, include piranhas, pacus, and their relatives, and currently comprise 98 valid species distributed throughout South America [16]. Several species of this fish group are economically important for commercial fishing and aquaculture, especially in the Amazon region [3, 25, 36]. Many phylogenetic studies based on different molecular markers (e.g., mtDNA control region, $12 \mathrm{~S}$ and $16 \mathrm{~S}$ rRNA) have suggested that the Serrasalmidae form three major phylogenetic lineages, i.e., the "pacu" lineage (including Colossoma, Mylossoma and Piaractus), the "Myleus-like pacus" lineage (including Mylesinus, Myleus, Ossubtus and Tometes), and the "true piranhas" lineage (including Catoprion, Metynnis, Pristobrycon, Pygocentrus, Pygopristis and Serrasalmus) [47, 48, 64]. Serrasalmid fish exhibit enormous monogenean diversity. So far, 92 monogenean species belonging to 15 genera have been recorded on these fish. Most of these records originated from Brazil during the 1990s, when at least 8 genera and 61 species of monogeneans were described from piranhas and their relatives [8].

According to morphological analyses carried out by Kritsky and Boeger [28], the Anacanthorinae seem to represent a monophyletic group within the Dactylogyridae. Van Every and Kritsky [65] used the morphological characters of the haptoral hooks and reproductive organs to infer phylogenetic relationships between species of Anacanthorus from the "true piranhas" from the central Amazon. They suggested that this host-parasite system is a suitable model for studying biogeography and coevolution in the neotropics, although there are still many gaps in our knowledge concerning their diversity and phylogeny (i.e., the phylogenetic position of Anacanthorus within the Dactylogyridae and interspecific relationships within the genus).

Using the complete SSU (18S rDNA), Müller et al. [45] performed a study on Anacanthorus penilabiatus Boeger, Husak \& Martins 1995 [6] and Mymarothecium viatorum Boeger, Piasecki \& Sobecka, 2002 [7] (Ancyrocephalinae), both parasites of the pacu Piaractus mesopotamicus (Holmberg, 1887), focusing on the phylogenetic position of these monogeneans within the Dactylogyridae. Recently, Graça et al. [20] investigated the coevolutionary processes between selected species of Anacanthorus and their hosts in southern Brazil, and identified host-parasite cospeciation at the level of host families (Serrasalmidae, Bryconidae and Erythrinidae) and their specific Anacanthorus spp.

Considering the richness of Anacanthorus (the highest of all genera parasitizing Characiformes in the neotropics), the high host specificity exhibited by Anacanthorus species, and the scarcity of phylogenetic studies focused on these dactylogyrids, the aim of this study was to investigate the phylogenetic position of Anacanthorus spp. within the Dactylogyridae that infest serrasalmids from two Brazilian river basins based on the analysis of partial $28 \mathrm{~S}$ rDNA sequences.

\section{Materials and methods}

\section{Specimen collection and processing}

Fish were caught by local fishermen with gill nets and hooks from the following localities in Brazil: the Miranda River $\left(20^{\circ} 11^{\prime} 27^{\prime \prime} \mathrm{S} ; 56^{\circ} 30^{\prime} 19^{\prime \prime} \mathrm{W}\right)$, the Negro River (Mato Grosso do Sul) $\left(19^{\circ} 34^{\prime} 40^{\prime \prime} \mathrm{S} ; 56^{\circ} 09^{\prime} 08^{\prime \prime} \mathrm{W}\right)$, the Upper Paraná River $\left(20^{\circ}\right.$ $45^{\prime} \mathrm{S} ; 53^{\circ} 16^{\prime} \mathrm{W}$ ), and the Xingu River $\left(3^{\circ} 12^{\prime} \mathrm{S}, 52^{\circ} 12^{\prime} \mathrm{W}\right.$ ) (see Table 1). Fish were examined for monogeneans immediately after capture. All experimental handling was carried out in compliance with animal safety and ethics rules issued by the Federal Rural University of Rio de Janeiro (UFRRJ). Gills excised from fish were placed in Petri dishes with tap water and examined for monogeneans using a dissecting microscope. Parasites were placed individually in a drop of water on a slide and the haptor of each specimen was excised from the body and preserved in absolute ethanol for molecular analyses. The rest of the body was mounted in a mixture of glycerine and ammonium picrate (GAP) and kept as a molecular voucher. Additionally, some entire specimens were mounted in GAP and kept as paragenophore specimens (see Astrin et al. [4] for terminology). Species determinations were mainly based on the morphology of the male copulatory organ and of the haptoral hooks following the original descriptions by Boeger and Kritsky [5], Van Every and Kritsky [65], and Boeger et al. [6]. After morphological evaluation, specimens fixed in GAP were remounted in 
Table 1. Species included in the phylogenetic analyses.

\begin{tabular}{|c|c|c|c|c|}
\hline Parasite species & Host species & Host family & Locality & $\begin{array}{c}\text { Accession } \\
\text { number }\end{array}$ \\
\hline \multicolumn{5}{|l|}{ Dactylogyridea } \\
\hline \multicolumn{5}{|l|}{ Dactylogyridae } \\
\hline Actinocleidus recurvatus Mizelle and Donahue, 1944 [41] & Lepomis gibbosus (Linnaeus) & Centrarchidae & River Dunaj, SR & AJ969951 \\
\hline Aliatrema cribbi Plaisance \& Kritsky, $2004[50]^{* *}$ & Chaetodon citrinellus (Cuvier, 1831) & Chaetodontidae & French Polynesia & AY820612 \\
\hline Ameloblastella chavarriai (Price, 1938) [53] & Rhamdia quelen (Quoy \& Gaimard, 1824) & Heptapteridae & Lake Catemaco, MX & KP056251 \\
\hline Ameloblastella sp. 16 (from Mendoza-Palmero et al. [39]) & $\begin{array}{l}\text { Hypophthalmus edentatus Spix \& Agassiz, } \\
1829\end{array}$ & Hypophtalmidae & River Nanay, PE & KP056255 \\
\hline Ancyrocephalus paradoxus Creplin, 1839 [10] & Sander lucioperca (Linnaeus) & Percidae & River Morava, CR & AJ969952 \\
\hline Ancyrocephalus percae (Ergens, 1966) [12] & Perca fluviatilis (Linnaeus) & Percidae & Lake Constance, GE & KF499080 \\
\hline Anacanthorus amazonicus Van Every \& Kritsky, 1992 [65] & Serrasalmus maculatus Kner, 1858 & Serrasalmidae & River Negro, BR & MH843721 \\
\hline Anacanthorus jegui Van Every \& Kritsky, 1992 [65] & Serrasalmus maculatus Kner, 1858 & Serrasalmidae & River Negro, BR & MH843720 \\
\hline $\begin{array}{l}\text { Anacanthorus lepyrophallus Kritsky, Boeger, and Van Every, } \\
1992[29]\end{array}$ & Serrasalmus maculatus Kner, 1858 & Serrasalmidae & River Baia, BR & MH843718 \\
\hline Anacanthorus maltai Boeger \& Kritsky, 1988 [5] & Pygocentrus nattereri Kner, 1858 & Serrasalmidae & River Miranda, BR & MH843716 \\
\hline $\begin{array}{l}\text { Anacanthorus paraxaniophallus Moreira, Carneiro, Ruz \& } \\
\text { Luque, } 2019 \text { [42] }\end{array}$ & $\begin{array}{l}\text { Serrasalmus marginatus Valenciennes, } \\
\quad 1837\end{array}$ & Serrasalmidae & River Paraná, BR & MH843717 \\
\hline Anacanthorus penilabiatus Boeger, Husak \& Martins, 1995 [6] & $\begin{array}{l}\text { Piaractus mesopotamicus (Holmberg, } \\
\text { 1887) }\end{array}$ & Serrasalmidae & River Paraná, BR & MH843719 \\
\hline Anacanthorus rondonensis Boeger \& Kritsky, 1988 [5] & Pygocentrus nattereri Kner, 1858 & Serrasalmidae & River Miranda, BR & MH843714 \\
\hline Anacanthorus thatcheri Boeger \& Kritsky, 1988 [5] & Pygocentrus nattereri Kner, 1858 & Serrasalmidae & River Miranda, BR & MH843715 \\
\hline Anacanthorus sp. 1 & Myleus setiger Müller \& Troschel, 1844 & Serrasalmidae & River Xingu, BR & MH843722 \\
\hline Bravohollisia roseta Lim, 1995 [34] & Pomadasys maculatus (Bloch, 1793) & Haemulidae & Guangdong, $\mathrm{CH}$ & DQ537364 \\
\hline Bychowskyella pseudobagri Akhmerow, 1952 [2] & Tachysurus fulvidraco (Richardson, 1846) & Bagridae & Guangdong, $\mathrm{CH}$ & EF100541 \\
\hline Dactylogyrus extensus Mueller and Van Cleave, 1932 [44] & Cyprinus carpio (Linnaeus) & Cyprinidae & River Morava, CR & AJ969944 \\
\hline Dactylogyrus inversus (Goto and Kikuchi, 1917) [18] & Lateolabrax japonicus (Cuvier, 1828) & Lateolabracidae & $\mathrm{CH}$ & AY548928 \\
\hline Euryhaliotrema perezponcei García-Vargas, Fajer-Ávila \& & Lutjanus guttatus (Steindachner, 1869) & Lutjanidae & Bay Cerritos, MX & HQ615996 \\
\hline \multicolumn{5}{|l|}{ Lamothe-Argumedo, 2008 [17] } \\
\hline Euryhaliotrematoides annulocirrus (Yamaguti, 1968) [70]** & Chaetodon vagabundus (Linnaeus) & Chaetodontidae & AUT & AY820613 \\
\hline Euryhaliotrematoides microphallus (Yamaguti, 1968) [70]** & Heniochus chrysostomus Cuvier, 1831 & Chaetodontidae & Palau & AY820617 \\
\hline Haliotrema angelopterum Plaisance, Bouamer \& Morand, 2004 & Chaetodon kleinii Bloch, 1790 & Chaetodontidae & Palau & AY820620 \\
\hline \multicolumn{5}{|l|}{ [49] } \\
\hline Haliotrema aurigae (Yamaguti, 1968) [70] & Chaetodon auriga Forsskål, 1775 & Chaetodontidae & AUT & AY820621 \\
\hline $\begin{array}{l}\text { Haliotrematoides guttati García-Vargas, Fajer-Ávila \& Lamothe- } \\
\text { Argumedo, } 2008 \text { [17] }\end{array}$ & Lutjanus guttatus (Steindachner, 1869) & Lutjanidae & Bay Cerritos, MX & HQ615993 \\
\hline Haliotrematoides spinatus Kritsky \& Mendoza-Franco in & Lutjanus guttatus (Steindachner, 1869) & Lutjanidae & Pacific Coast, MX & КС663679 \\
\hline \multicolumn{5}{|l|}{ Kritsky, Yang \& Sun, 2009 [32] } \\
\hline Ligictaluridus pricei (Mueller, 1936) [43] & Ameiurus nebulosus (Lesueur, 1819) & Ictaluridae & River Moldau, CR & AJ969939 \\
\hline $\begin{array}{l}\text { Mymarothecium viatorum Boeger, Piasecki and Sobecka, } \\
\text { 2002 [7] }\end{array}$ & $\begin{array}{l}\text { Piaractus mesopotamicus (Holmberg, } \\
\text { 1887) }\end{array}$ & Serrasalmidae & River Paraná, BR & MH843723 \\
\hline Onchocleidus similis (Mueller, 1936) [43] & Lepomis gibbosus (Linnaeus) & Centrarchidae & River Danube, SR & AJ969938 \\
\hline Onchocleidus sp. & Lepomis macrochirus Rafinesque, 1819 & Centrarchidae & Guangzhou, $\mathrm{CH}$ & AY841873 \\
\hline
\end{tabular}

(Continued on next page) 
Table 1. (Continued)

\begin{tabular}{|c|c|c|c|c|}
\hline Parasite species & Host species & Host family & Locality & $\begin{array}{l}\text { Accession } \\
\text { number }\end{array}$ \\
\hline $\begin{array}{l}\text { Parasciadicleithrum octofasciatum Mendoza-Palmero, Blasco- } \\
\text { Costa, Hernández-Mena \& Pérez-Ponce de León, } 2017 \text { [40] }\end{array}$ & Rocio octofasciata (Regan, 1903) & Cichlidae & $\begin{array}{l}\text { Unnamed creek in } \\
\text { Ejido Reforma } \\
\text { Agraria, MX }\end{array}$ & KY305885 \\
\hline Pseudodactylogyrus anguillae (Yin \& Sproston, 1948) [71] & Anguilla anguilla (Linnaeus) & Anguillidae & River Dunaj, SR & AJ969950 \\
\hline Pseudodactylogyrus bini (Kikuchi, 1929) [26] & Anguilla anguilla (Linnaeus) & Anguillidae & $\begin{array}{l}\text { Neusiedler Lake, } \\
\text { AUS }\end{array}$ & AJ969949 \\
\hline Pseudohaliotrema sphincteroporus Yamaguti, 1953 [69] & Siganus doliatus Guérin-Méneville, 1829 & Siganidae & Green Island, AUT & AF382058 \\
\hline Quadriacanthus kobiensis На Кy, 1968 [22] & Clarias batrachus (Linnaeus) & Clariidae & Guangzhou, CH & AY841874 \\
\hline $\begin{array}{l}\text { Sciadicleithrum meekii Mendoza-Franco, Scholz \& Vidal- } \\
\text { Martínez, } 1997 \text { [38] }\end{array}$ & Thorichthys meeki Brind, 1918 & Cichlidae & $\begin{array}{l}\text { Unnamed creek in } \\
\text { Ejido Reforma } \\
\text { Agraria, MX }\end{array}$ & KY305889 \\
\hline $\begin{array}{l}\text { Sciadicleithrum splendidae Kritsky, Vidal-Martínez \& } \\
\text { Rodríguez-Canul, } 1994 \text { [31] }\end{array}$ & $\begin{array}{l}\text { Parachromis friedrichsthalii (Heckel, } \\
\text { 1840) }\end{array}$ & Cichlidae & $\begin{array}{l}\text { Laguna El Vapor, } \\
\text { MX }\end{array}$ & KY305890 \\
\hline Tetrancistrum sp. & Siganus fuscescens (Houttuyn, 1782) & Siganidae & Heron Island, AUT & AF026114 \\
\hline Thaparocleidus asoti (Yamaguti, 1937) [68] & Parasilurus asotus (Linnaeus) & Siluridae & Chongqing City, $\mathrm{CH}$ & DQ157669 \\
\hline Thaparocleidus siluri (Zandt, 1924) [73] & Silurus glanis (Linnaeus) & Siluridae & River Morava, CR & AJ969940 \\
\hline Unibarra paranoplatensis Suriano \& Incorvaia, 1995 [61] & Aguarunichthys torosus Stewart, 1986 & Pimelodidae & Santa Clara, PE & KP056219 \\
\hline $\begin{array}{l}\text { Vancleaveus janauacaensis Kritsky, Thatcher and Boeger, } 1986 \\
\text { [30] }\end{array}$ & $\begin{array}{l}\text { Pterodoras granulosus (Valenciennes, } \\
\text { 1821) }\end{array}$ & Doradidae & River Itaya, PE & KP056240 \\
\hline \multicolumn{5}{|l|}{ Pseudomurraytrematidae } \\
\hline Pseudomurraytrema sp.* & Catostomus ardens Jordan \& Gilbert, 1881 & Catostomidae & Snake River, Idaho & AF382059 \\
\hline \multicolumn{5}{|l|}{ Tetraonchinea } \\
\hline Anoplodiscidae & & & & \\
\hline $\begin{array}{l}\text { Anoplodiscus cirrusspiralis Roubal, Armitage \& Rohde, } 1983 \\
\text { [56]* }\end{array}$ & Sparus aurata (Linnaeus) & Sparidae & Sydney, AUT & AF382060 \\
\hline \multicolumn{5}{|l|}{ Tetraonchidae } \\
\hline Tetraonchus monenteron (Wagener, 1857) [67]* & Esox lucius (Linnaeus) & Esocidae & River Morava, CR & AJ969953 \\
\hline \multicolumn{5}{|l|}{ Monocotylidea } \\
\hline Calicotyle affinis Scott, 1911 [57]* & Chimaera monstrosa (Linnaeus) & Chimaeridae & Norway & AF382061 \\
\hline Clemacotyle australis Young, 1967 [72]* & Aetobatus narinari (Euphrasen, 1790) & Myliobatidae & Heron Island, AUT & AF348350 \\
\hline Decacotyle lymmae Young, 1967 [72]* & Aetobatus narinari (Euphrasen, 1790) & Myliobatidae & Heron Island, AUT & AF348359 \\
\hline Dendromonocotyle octodiscus Hargis, 1955 [23]* & $\begin{array}{l}\text { Dasyatis americana (Hildebrand \& } \\
\quad \text { Schroeder, 1928) }\end{array}$ & Dasyatidae & Gulf of Mexico & AF348352 \\
\hline
\end{tabular}

${ }_{* *}^{*}$ Species used as outgroups.

** Euryhaliotrematoides and Aliatrema were placed in subjective synonymy with Euryhaliotrema [27]

Species sequenced in this study are shown in bold.

Abbreviations: AUS - Austria, AUT - Australia, BR - Brazil, CH - China, CR - Czech Republic, GE - Germany, MX - Mexico, PE - Peru, SR - Slovak Republic. 
Canada balsam according to the procedure described by Ergens [13]. Voucher specimens were deposited in the Helminthological Collection of the Institute Oswaldo Cruz (CHIOC), Rio de Janeiro, Brazil, under the catalogue numbers $40046 \mathrm{a}-\mathrm{b}$ and 40047 and in the Helminthological Collection of the Institute of Parasitology of the Czech Academy of Sciences, (IPCAS), Czech Republic, under the catalogue numbers M-702 - M-710.

\section{DNA extraction, amplification, and sequencing}

DNA extraction was carried out in $200 \mu \mathrm{l}$ of a $5 \%$ suspension of Chelex ${ }^{\mathrm{TM}}$ in deionized water containing $2 \mu \mathrm{l}$ proteinase $\mathrm{K}$, followed by incubation at $56{ }^{\circ} \mathrm{C}$ for $3 \mathrm{~h}$ and boiling at $95{ }^{\circ} \mathrm{C}$ for $8 \mathrm{~min}$. The partial 28S rRNA gene region (D1-D3) was amplified using primers C1 and D2 [24] or U178 and L1642 [35]. For the $\mathrm{C} 1$ and $\mathrm{D} 2$ primers, PCR reactions were performed in a final volume of $15 \mu$ l containing $1 \times$ PCR buffer, $1.5 \mathrm{mM}$ of $\mathrm{MgCl}_{2}, 0.2 \mathrm{mM}$ of dNTPs, $0.5 \mathrm{mM}$ of each oligonucleotide primer, $1 \mathrm{U}$ of Taq DNA polymerase (Fermentas), $6.6 \mathrm{mg} / \mathrm{ml}$ of BSA, and $5 \mu \mathrm{l}$ of genomic DNA, using the following cycling parameters: denaturation at $94{ }^{\circ} \mathrm{C}$ for $2 \mathrm{~min}$, followed by 39 cycles of $94{ }^{\circ} \mathrm{C}$ for $20 \mathrm{~s}$, annealing at $58{ }^{\circ} \mathrm{C}$ for $30 \mathrm{~s}$, and elongation at $72{ }^{\circ} \mathrm{C}$ for $1 \mathrm{~min} 30 \mathrm{~s}$, with a final elongation at $72{ }^{\circ} \mathrm{C}$ for $10 \mathrm{~min}$. For the second pair of primers, PCR reactions were performed in a final volume of $25 \mu \mathrm{l}$ containing $1 \times$ PCR buffer, $3 \mathrm{mM}$ of $\mathrm{MgCl}_{2}, 0.2 \mathrm{mM}$ of dNTP's, $0.5 \mathrm{mM}$ of each oligonucleotide primer, $1 \mathrm{U}$ of Platinum Taq DNA polymerase (Invitrogen), $0.4 \mathrm{mg} / \mathrm{ml}$ of BSA, and $2.5 \mu \mathrm{l}$ of genomic DNA, using the cycling profile described in Mendoza-Palmero et al. [39]. The PCR products were checked on $1 \%$ agarose gel and purified using an ExoSAP-IT kit (Ecoli, Bratislava, Slovakia), following the manufacturer's instructions. Purified products were directly sequenced using PCR primer pair C1-D2 or U178-L1642 and two additional internal primers (1200F and 1200R, see Lockyer et al. [35]) with a BigDye Terminator Cycle Sequencing kit (Applied Biosystems, Foster City, CA, USA). Sequencing was performed on an ABI 3130 Genetic Analyzer (Applied Biosystems).

Contiguous sequences were assembled in Geneious (Geneious ver. 9 created by Biomatters, available from http:// www.geneious.com/) and deposited in the GenBank database under the accession numbers listed in Table 1.

\section{Phylogenetic analyses}

Nine species of Anacanthorus and Mymarothecium viatorum (host species are shown in Table 1) were sequenced for the partial 28S rRNA gene and aligned with 35 species belonging to the Dactylogyridea and four species of the Monocotylidea retrieved from GenBank (see Table 1). Sequences were aligned with the CLUSTAL W algorithm [63] implemented in Geneious. Ambiguously aligned regions were removed from the alignment with GBlocks v. 0.91 [62], using less stringent selection. Phylogenetic analyses were performed using species of Monocotylidae, Tetraonchidae, Anoplodiscidae, and Pseudomurraytrematidae as outgroups (see Table 1 for species). The substitution model TVM + I + G (the transversion model including the proportion of invariable sites and a gamma distribution), selected by the jModelTest [52] using the Bayesian information criterion, was used for Maximum Likelihood (ML) and Bayesian Inference (BI) analyses. The search for the ML tree and bootstrap resampling with 1000 replications were performed using PHYML [21] implemented in Geneious. BI analyses were performed using MrBayes v. 3.2 [55], running four Monte Carlo Markov chains for $10^{7}$ generations, with trees sampled every $10^{3}$ generations and the first 1000 samples discarded as "burn in". In order to check the convergence and to confirm that the effective sample size (ESS) of each parameter was adequate for providing reasonable estimates of the variance in model parameters (i.e., ESS values >200), Tracer v. 1.6 [54] was used.

\section{Results}

New partial 28S rDNA sequences were obtained for nine species of Anacanthorus (Anacanthorus amazonicus Van Every \& Kritsky, 1992 [65], Anacanthorus jegui Van Every \& Kritsky, 1992 [65], Anacanthorus lepyrophallus Kritsky, Boeger, and Van Every, 1992 [29], Anacanthorus maltai Boeger \& Kritsky, 1988 [5], Anacanthorus paraxaniophallus Moreira, Carneiro, Ruz \& Luque, 2019 [42], Anacanthorus penilabiatus Boeger, Husak \& Martins, 1995 [6], Anacanthorus rondonensis Boeger \& Kritsky, 1988 [5], Anacanthorus thatcheri Boeger \& Kritsky, 1988 [5] and Anacanthorus sp. 1) and Mymarothecium viatorum, and varied from $612 \mathrm{bp}$ to $716 \mathrm{bp}$ (when using the $\mathrm{C} 1$ and D2 primers) and from $1425 \mathrm{bp}$ to $1434 \mathrm{bp}$ (when using the U178 and L1642 primers). Specimens identified as Anacanthorus sp. 1 represented an undescribed species parasitizing Myleus setiger. An unambiguous alignment of all analyzed species of the Dactylogyridea and Monocotylidea spanned 391 positions and included 205 parsimony-informative characters, 227 variable characters, and 164 conserved characters. ML and BI analyses generated phylogenetic trees with similar general topology and the monophyly of Anacanthorus was strongly supported by both analyses (Fig. 1). The Anacanthorinae, represented only by Anacanthorus spp. in this study, appeared to form a monophyletic group clustering with clade A comprising solely freshwater species of Ancyrocephalinae and the clade of Ancylodiscoidinae spp. Anacanthorus penilabiatus showed the basal position within the clade of Anacanthorus spp. Even though the ML and BI phylogenetic trees displayed the same topology, the status of Anacanthorus as a sister group to clade A of freshwater Ancyrocephalinae was only weakly supported by ML analysis. Mymarothecium viatorum, the next host-specific monogenean representative parasitizing serrasalmids, was positioned within clade A of the Ancyrocephalinae.

Clade B, including representatives of both freshwater and marine species of the Ancyrocephalinae, was well supported by BI analysis and weakly supported by ML analysis. The Dactylogyrinae formed a monophyletic sister group to Pseudodactylogyrinae (only weakly supported) and clustered with clade B of Ancyrocephalinae. Within clade B of Ancyrocephalinae, five marine species formed a well-supported group (clade C) on the basis of both analyses.

Within the Anacanthorinae i.e., Anacanthorus, the phylogenetic relationships among Anacanthorus seemed to reflect the phylogeny of their serrasalmid hosts. Anacanthorus 


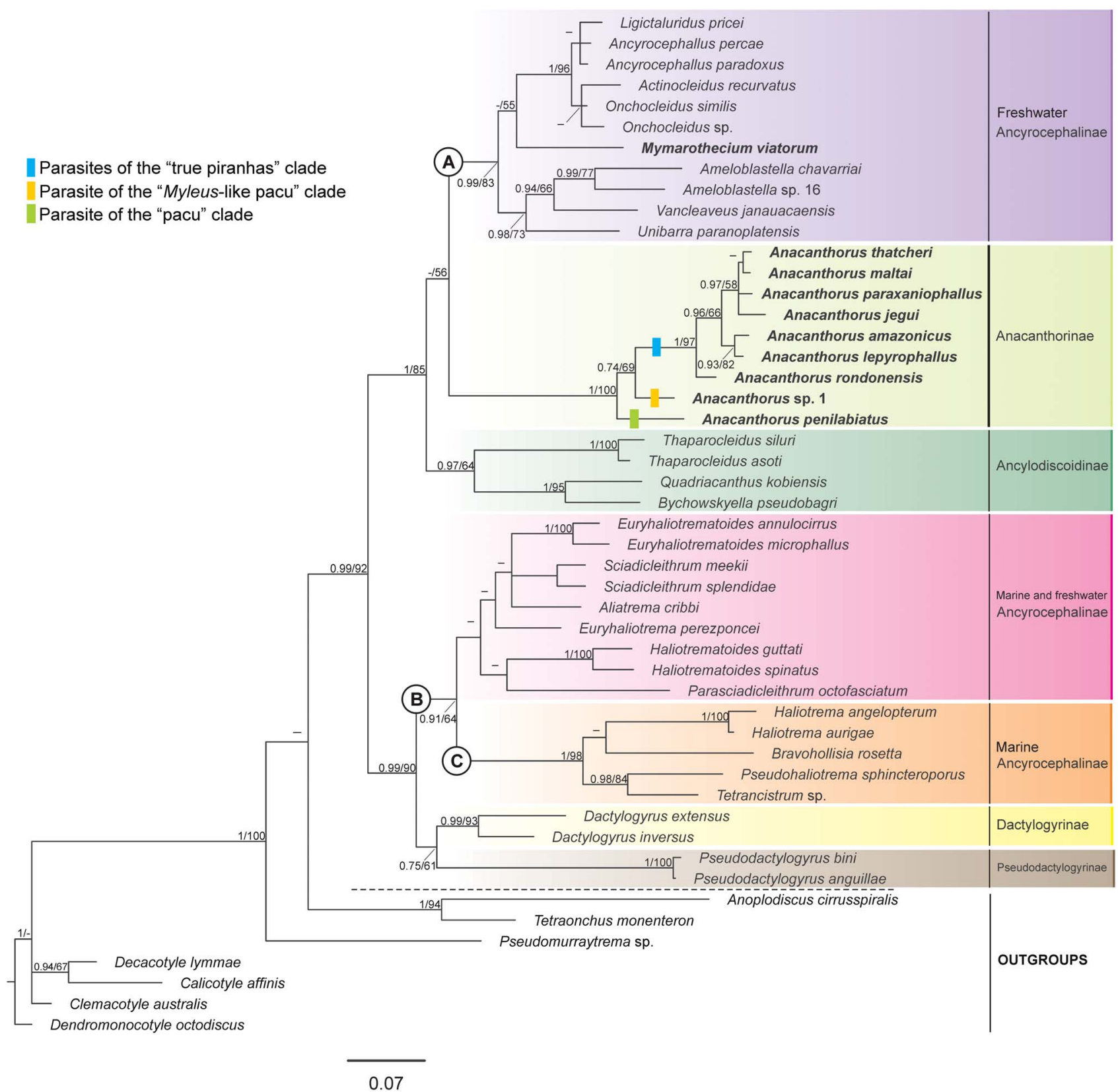

Figure 1. Consensus Bayesian topology from the phylogenetic analysis of partial 28S rDNA of 49 species of monogeneans. BI posterior probabilities and ML bootstrap values are shown at the nodes. Posterior probabilities $<0.7$ are not reported. Bootstrap values $<50$ are not reported. Species sequenced in the present study are shown in bold.

penilabiatus from Piaractus mesopotamicus, a member of the "pacu" clade, showed the basal position within Anacanthorus; the following position was held by Anacanthorus sp. 1 from Myleus setiger (this position was weakly or moderately supported by BI and ML analyses, respectively), a representative of the "Myleus-like pacus" clade. Finally, the large group of Anacanthorus included two clades of species from hosts representing the "true piranhas" lineage, the first one well supported and including $A$. lepyrophallus and $A$. amazonicus, the second one including A. paraxaniophallus, A. jegui, A. thatcheri and A. maltai. A. rondonensis from Pygocentrus nattereri, a representative of the "true piranhas" lineage, showed the basal position in this large Anacanthorus group.

\section{Discussion}

In the present study, and for the first time, the phylogenetic position of Anacanthorus within the Dactylogyridae was evaluated on the basis of analyses of partial 28S rDNA sequences. Representatives of five subfamilies within the Dactylogyridae, i.e., Ancyrocephalinae, Ancylodiscoidinae, Anacanthorinae, Dactylogyrinae, and Pseudodactylogyrinae, were included in the analyses. Using molecular data, we confirmed the monophyly of the Anacanthorinae (here represented only by Anacanthorus), in accordance with previous studies based on morphological characters [28, 65]. We did not include any member of Anacanthoroides in the phylogenetic analyses. 
Our results show that phylogenetic patterns between Anacanthorus spp. correspond to those between the Serrasalmidae. Ortí et al. [47] inferred the first molecular phylogeny of Serrasalmidae using mtDNA (12S and $16 \mathrm{~S}$ rRNA) markers, and found three major lineages, (i) a clade including the "pacus" in the most basal position, followed by (ii) the clade including "Myleus-like pacus" species, and (iii) a clade including the most diverse group of Serrasalmidae, represented by the "true piranhas". They also determined the placement of Acnodon as a sister group to the two last lineages and suggested the paraphyly of some genera, i.e., Myleus, Pristobrycon and Serrasalmus. Later, Ortí et al. [48] performed analyses based on complete sequences of the mtDNA control region (D-loop) and on partial sequences of $12 \mathrm{~S}$ and $16 \mathrm{~S}$ rRNA, and their findings corroborated the previous division into three main lineages; they also suggested that other serrasalmid genera are not monophyletic. Finally, more recently, Thompson et al. [64] performed a robust phylogenetic analysis based on the sequences of 10 nuclear genes (two exons and eight introns) and the mtDNA control region. Their results agreed with previous studies on the phylogenetic relationships within serrasalmids based on mtDNA and confirmed that there are still many gaps to fill with regard to the taxonomy of this fish group.

Our results may suggest that cospeciation processes played a role between Anacanthorus spp. and their serrasalmid hosts (at least at the level of three serrasalmid lineages). Recently, Graça et al. [20] suggested that there is cospeciation between Anacanthorus and their host lineages representing different families (Serrasalmidae, Bryconidae and Erythrinidae), even though duplications were the most frequent coevolutionary event in the speciation of Anacanthorus parasitizing species of the same family. In fact, cospeciation between monogeneans and their hosts was not found to be significant in some extensively studied groups such as Lamellodiscus [11], Gyrodactylus [74], Dactylogyrus [58, 59] and Cichlidogyrus [37].

The phylogenetic relationships among Anacanthorus spp. also seem to reflect the similarity in the morphology of the copulatory complex. Although we did not analyze all species previously morphologically evaluated by Van Every and Kritsky [65], their phylogenetic reconstruction using the morphology of copulatory complex is similar to our phylogenetic reconstruction using molecular data (i.e., the species analyzed in both studies exhibited the same phylogenetic relationships). However, to effectively investigate the congruence of phylogenies built on molecular and morphological data, the sequencing of a larger dataset of Anacanthorus species is necessary in future studies, potentially focusing on mapping the characters of the copulatory complex into the molecular phylogenetic reconstruction.

According to our results, species of Anacanthorus formed a clade including the group of freshwater members of the Ancyrocephalinae (clade A) and the group of species of Ancylodiscoidinae. At the same time, we showed that Mymarothecium viatorum, an exclusive parasite of the "pacu" lineage, was positioned within freshwater Ancyrocephalinae. Using complete 18S rDNA sequences, Müller et al. [45] showed that M. viatorum clustered with A. penilabiatus. Both ribosomal markers (28S and 18S rDNA) have been widely used to reconstruct the phylogenies of monogeneans, and in many cases they have produced similar topologies (e.g., Plaisance et al. [51], Francová et al. [15], Verma et al. [66]); thus, the finding of Müller et al. [45] is due to the lack of sequences of species closely related to Anacanthorus species (i.e., the absence of the representatives of freshwater Ancyrocephalinae).

We conclude that Anacanthorus and their serrasalmid hosts can provide a useful model for studying host-parasite biogeography and coevolution in the neotropics. However, to perform cophylogenetic analyses, future studies are needed focusing on a wider spectrum of host species and their specific Anacanthorus spp. Additional sampling of the representatives of other monogenean genera parasitizing serrasalmids will allow us to investigate the phylogenetic relationships among such diverse monogeneans parasitizing the same host group.

Acknowledgements. We wish to thank Camila Pantoja, Maria Catarina Moraes and Philippe Alves from the Universidade Federal Rural do Rio de Janeiro, Rio de Janeiro (Brazil) and Tomáš Scholz from the Institute of Parasitology, České Budějovice (Czech Republic) for their help with material collection and parasitological examination. We are also grateful to Emil José Hernández Ruz and Jânio da Silva Carneiro from the Universidade Federal do Pará, Altamira (Brazil), and Luiz Eduardo Roland Tavares from the Universidade Federal do Mato Grosso do Sul, Campo Grande (Brazil) for providing the facilities during the field trips. We would also like to thank Dr. Douglas McIntosh from the Department of Animal Parasitology, UFRRJ and Kristýna Koukalová from the Department of Botany and Zoology of the Faculty of Science of the Masaryk University, Brno (Czech Republic) for their technical support on sample sequencing. JM was funded by a Doctoral fellowship from CAPES (Coordenação de Aperfeiçoamento de Pessoal de Nível Superior, Brazil)/PDSE/ Process number $\{88881.134872 / 2016-01\}$, and the Conselho Nacional de Desenvolvimento Cientifico e Tecnológico (CNPq) provided grants to JLL (Nos. 474077/2011-0, 304254/2011-8, 402665/ 2012-0). All molecular analyses as well as personal costs for A $\breve{S}$ were funded by the Czech Science Foundation, ECIP project No. P505/12/G112. We kindly thank Matthew Nicholls for English revision of the final draft.

\section{References}

1. Acosta AA, Mendoza-Palmero CA, da Silva RJ, Scholz T. 2019. A new genus and four new species of dactylogyrids (Monogenea), gill parasites of pimelodid catfishes (Siluriformes: Pimelodidae) in South America and the reassignment of Urocleidoides megorchis Mizelle et Kritsky, 1969. Folia Parasitologica, 66, 4.

2. Akhmerov AK. 1952. New species of monogenetic trematodes of fish from the river Amur. Parazitologicheski Sbornik, 14, $181-212$

3. Araujo-Lima C, Goulding M. 1997. So fruitful a fish: ecology, conservation, and aquaculture of the Amazon's Tambaqui. New York, NY: Columbia University Press.

4. Astrin JJ, Zhou X, Misof B. 2013. The importance of biobanking in molecular taxonomy, with proposed definitions for vouchers in a molecular context. ZooKeys, 365, 67-70.

5. Boeger WA, Kritsky DC. 1988. Neotropical Monogenea. 12. Dactylogyridae from Serrasalmus nattereri (Cypriniformes, Serrasalmidae) and aspects of their morphologic variation and distribution in the Brazilian Amazon. Proceedings of the Helminthological Society of Washington, 55, 188-213.

6. Boeger WA, Husak WS, Martins ML. 1995. Neotropical Monogenoidea. 25. Anacanthorus penilabiatus n. sp. 
(Dactylogyridae, Anacanthorinae) from Piaractus mesopotamicus (Osteichthyes, Serrasalmidae), cultivated in the State of São Paulo, Brazil. Memórias do Instituto Oswaldo Cruz, 90, 699701.

7. Boeger WA, Piasecki W, Sobecka E. 2002. Neotropical Monogenoidea. 44. Mymarothecium viatorum sp. n. (Ancyrocephalinae) from the gills of Piaractus brachypomus (Serrasalmidae, Teleostei) captured in a warm-water canal of a power plant in Szczecin, Poland. Acta Ichthyologica et Piscatoria, 2, 157-162.

8. Boeger WA, Vianna RT. 2006. Monogenoidea, in Amazon fish parasites, 2nd edn. Thatcher VE, Editor. Pensoft: Bulgaria. p. 42-116.

9. Cohen SC, Justo MC, Kohn A. 2013. South American monogenoidea parasites of fishes, amphibians and reptiles. Oficina de Livros: Rio de Janeiro.

10. Creplin FCH. 1839. Eingeweidewürmer, Binnenwürmer, Thierwürme. Allg. Encycl. Wissensch. u. Kiinste (Ersch u. Gruber), 1. sect., 32, 277-302.

11. Desdevises Y, Morand S, Jousson O, Legendre P. 2002. Coevolution between Lamellodiscus (Monogenea: Diplectanidae) and Sparidae (Teleostei): the study of a complex hostparasite system. Evolution, 56, 2459-2471.

12. Ergens R. 1966. Revision of the helminthofauna of fishes in Czechoslovakia III. Genus Ancyrocephalus (s. 1.) Creplin, 1839 (Monogenoidea: Dactylogyridae). Folia Parasitologica, 13, 28-35.

13. Ergens R. 1969. The suitability of ammonium picrate-glycerin in preparing slides of lower Monogenoidea. Folia Parasitologica, 16, 320 .

14. Franceschini L, Zago AC, Muller MI, Francisco CJ, Takemoto RM, da Silva RJ. 2018. Morphology and molecular characterization of Demidospermus spirophallus n. sp., D. prolixus n. sp. (Monogenea: Dactylogyridae) and a redescription of D. anus in siluriform catfish from Brazil. Journal of Helminthology, 92, 228-243.

15. Francová K, Seifertová M, Blažek R, Gelnar M, Mahmoud ZN, Řehulková E. 2017. Quadriacanthus species (Monogenea: Dactylogyridae) from catfishes (Teleostei: Siluriformes) in eastern Africa: new species, new records and first insights into interspecific genetic relationships. Parasites \& Vectors, 10, 361.

16. Froese R, Pauly D. 2018. FishBase. World Wide Web electronic publication. Available at https://www.fishbase.org, Version (06/2018). Accessed 22 August 2018.

17. Garcia-Vargas F, Fajer-Avila EJ, Lamothe-Argumedo R. 2008. Two new species of Dactylogyridae (Monogenoidea) on rose spotted snapper, Lutjanus guttatus (Osteichthyes: Lutjanidae), from the coasts of Nayarit and Sinaloa, Mexico. Zootaxa, 1729, $61-68$.

18. Goto S, Kikuchi H. 1917. Two new trematodes of the family Gyrodactylidae. Journal of the College of Science, Imperial University of Tokyo, 39, 1-22.

19. Graça RJ, Ueda BH, Oda FH, Takemoto RM. 2013. Monogenea (Platyhelminthes) parasites from the gills of Hoplias aff. malabaricus (Bloch, 1794) (Pisces: Erythrinidae) in the Upper Paraná River Floodplain, states of Paraná and Mato Grosso do Sul, Brazil. Check List, 9, 1484-1487.

20. Graça RJ, Fabrin TMC, Gasques LS, Prioli SMAP, Balbuena JA, Prioli AJ, Takemoto RM. 2018. Topological congruence between phylogenies of Anacanthorus spp. (Monogenea: Dactylogyridae) and their Characiformes (Actinopterygii) hosts: a case of host-parasite cospeciation. PLoS One, 13, e0193408.

21. Guindon S, Gascuel O. 2003. A simple, fast, and accurate algorithm to estimate large phylogenies by maximum likelihood. Systematic Biology, 52, 696-704.
22. Ha KY. 1968. New species of monogeneans from freshwater fishes of North Viet Nam. Part I. Parazitologiya, 2, 297-301.

23. Hargis WJ. 1955. Monogenetic trematodes of Gulf of Mexico fishes. Part V. The superfamily Capsaloidea. Transactions of the American Microscopical Society, 74, 203-225.

24. Hassouna N, Michot B, Bachellerie JP. 1984. The complete nucleotide sequence of mouse $28 \mathrm{~S}$ rRNA gene. Implications for the process of size increase of the large subunit rRNA in higher eukaryotes. Nucleic Acids Research, 12, 3563-3583.

25. Junk WJ. 1984. Ecology, fisheries and fish culture in Amazonia, in The Amazon, limnology and landscape ecology of a mighty tropical river and its Basin, Sioli H. Dr W, Editor. Junk Publishers: Dordrecht. p. 443-476.

26. Kikuchi H. 1929. Two new species of Japanese trematodes belonging to Gyrodactylidae. Annotationes Zoologicae Japonensis, 12, 175-186.

27. Kritsky DC. 2012. Dactylogyrids (Monogenoidea: Polyonchoinea) parasitizing the gills of snappers (Perciformes: Lutjanidae): revision of Euryhaliotrema with new and previously described species from the Red Sea, Persian Gulf, the eastern and Indo-west Pacific Ocean, and the Gulf of Mexico. Zoologia, 29, 227-276.

28. Kritsky DC, Boeger WA. 1989. The phylogenetic status of the Ancyrocephalidae Bychowsky, 1937 (Monogenea: Dactylogyroidea). Journal of Parasitology, 75, 207-211.

29. Kritsky DC, Boeger WA, Van Every LR. 1992. Neotropical Monogenoidea. 17. Anacanthorus Mizelle and Price, 1965 (Dactylogyridae, Anacanthorinae) from characoid fishes of the Central Amazon. Journal of the Helminthological Society of Washington, 59, 25-51.

30. Kritsky DC, Thatcher VE, Boeger WA. 1986. Neotropical Monogenea. 8. Revision of Urocleidoides (Dactylogyridae, Ancyrocephalinae). Proceedings of the Helminthological Society of Washington, 53, 1-37.

31. Kritsky DC, Vidal-Martínez VM, Rodríguez-Canul R. 1994. Neotropical Monogenoidea. 19. Dactylogyridae of cichlids (Perciformes) from the Yucatan Peninsula, with descriptions of three new species of Sciadicleithrum Kritsky, Thatcher, and Boeger, 1989. Journal of the Helminthological Society of Washington, 61, 26-33.

32. Kritsky DC, Yang T, Sun Y. 2009. Dactylogyrids (Monogenoidea, Polyonchoinea) parasitizing the gills of snappers (Perciformes, Lutjanidae): Proposal of Haliotrematoides n. gen. and descriptions of new and previously described species from marine fishes of the Red Sea, the eastern and Indo-west Pacific Ocean, Gulf of Mexico and Caribbean Sea. Zootaxa, 1970, 151.

33. Leão MS, Clemente SCS, Cohen SC. 2015. Anacanthorus toledoensis n. sp. and Mymarothecium ianwhittingtoni $\mathrm{n}$. sp. (Dactylogyridae: Monogenoidea) parasitizing cage-reared Piaractus mesopotamicus (Characiformes, Characidae) in the State of Paraná, Brazil. Comparative Parasitology, 82, 269-274.

34. Lim LHS. 1995. Bravohollisia Bychowsky \& Nagibina, 1970 and Caballeria Bychowsky \& Nagibina, 1970 (Monogenea: Ancyrocephalidae) from Pomadasys hasta (Bloch) (Pomadasyidae), with the description of a new attachment mechanism. Systematic Parasitology, 32, 211-224.

35. Lockyer AE, Olson PD, Littlewood DTJ. 2003. Utility of complete large and small subunit rRNA genes resolving the phylogeny of the Neodermata (Platyhelminthes): implications and a review of the cercomer theory. Biological Journal of the Linnaean Society, 78, 155-171.

36. Marshall E. 1995. Homely fish draws attention to Amazon deforestation. Science, 267, 814. 
37. Mendlová M, Desdevises Y, Civáňová K, Pariselle A, Šimková A. 2012. Monogeneans of West African cichlid fish: evolution and cophylogenetic interactions. PLoS One, 7, e37268.

38. Mendoza-Franco EF, Scholz T, Vidal-Martinez VM. 1997. Sciadicleithrum meekii sp. n. (Monogenea: Ancyrocephalinae) from the gills of Cichlasoma meeki (Pisces: Cichlidae) from cenotes $(=$ sinkholes $)$ of the Yucatan Peninsula, Mexico. Folia Parasitologica, 44, 205-208.

39. Mendoza-Palmero CA, Blasco-Costa I, Scholz I. 2015. Molecular phylogeny of Neotropical monogeneans (Platyhelminthes: Monogenea) from catfishes (Siluriformes). Parasites \& Vectors, 8,164 .

40. Mendoza-Palmero CA, Blasco-Costa I, Hernández-Mena D, de León GPP. 2017. Parasciadicleithrum octofasciatum n. gen., n. sp. (Monogenoidea: Dactylogyridae), parasite of Rocio octofasciata (Regan) (Cichlidae: Perciformes) from Mexico characterised by morphological and molecular evidence. Parasitology International, 66, 152-162.

41. Mizelle JD, Donahue MA. 1944. Studies on monogenetic trematodes. XI. Dactylogyridae from Algonquin Park fishes. American Midland Naturalist, 31, 600-624.

42. Moreira J, Carneiro JS, Ruz EJ, Luque JL. 2019. New species and records of Anacanthorus (Monogenea: Dactylogyridae) parasitizing serrasalmid fish (Characiformes) from Brazil, including molecular data. Acta Parasitologica, in press.

43. Mueller JF. 1936. New gyrodactyloid trematodes from North American fishes. Transactions of the American Microscopical Society, 55, 457-464.

44. Mueller JF, Van Cleave HJ. 1932. Parasites of Oneida Lake fishes. Part II. Descriptions of new species and some general taxonomic considerations, especially concerning the trematoda family Heterophyidae. Roosevelt Wild Life Annals, 3, 79-137.

45. Müller MI, Ceccarelli PS, Ueta MT. 2016. Supplementary studies on Anacanthorus penilabiatus and Mymarothecium viatorum (Monogenea: Dactylogyridae) from Piaractus mesopotamicus (Characiformes: Serrasalmidae) in Brazil. Acta Parasitologica, 61, 508-515.

46. Oliveira MSB, Adriano EA, Tavares-Dias M, Correa LL. 2019. Community of Monogenea in populations of Cichla monoculus from two tributaries of the Amazon River in the Northern Brazil. Helminthologia, 56, 1-10.

47. Ortí G, Petry P, Porto JIR, Jégu M, Meyer A. 1996. Patterns of nucleotide change in mitochondrial ribosomal RNA genes and the phylogeny of piranhas. Journal of Molecular Evolution, 42, $169-182$.

48. Ortí G, Sivasundar A, Dietz K, Jégu M. 2008. Phylogeny of the Serrasalmidae (Characiformes) based on mitochondrial DNA sequences. Genetics and Molecular Biology, 31, 343-351.

49. Plaisance L, Bouamer S, Morand S. 2004. Description and redescription of Haliotrema species (Monogenoidea: Poloyonchoinea: Dactylogyridae) parasitizing butterfly fishes (Teleostei: Chaetodontidae) in the Indo-West Pacific Ocean. Parasitology Research, 93, 72-78.

50. Plaisance L, Kritsky DC. 2004. Dactylogyrids (Platyhelminthes: Monogenoidea) parasitizing butterfly fishes (Teleostei: Chaetodontidae) from the coral reefs of Palau, Moorea, Wallis, New Caledonia, and Australia: species of Euryhaliotrematoides n. gen. and Aliatrema n. gen. Journal of Parasitology, 90, 328342 .

51. Plaisance L, Littlewood DTJ, Olson PD, Morand S. 2005. Molecular phylogeny of gill monogeneans (Platyhelminthes, Monogenea, Dactylogyridae) and colonization of Indo-West Pacific butterflyfish hosts (Perciformes, Chaetodontidae). Zoologica Scripta, 34, 425-436.

52. Posada D. 2008. jModelTest: phylogenetic model averaging. Molecular Biology and Evolution, 25, 1253-1256.
53. Price EW. 1938. The monogenetic trematodes of Latin America. Livro Jubliar Professor Travassos, Rio de Janeiro, Brazil, 3, 407-413.

54. Rambaut A, Suchard MA, Xie D, Drummond AJ. 2014. Tracer v1.6. World Wide Web electronic publication. Available at http://tree.bio.ed.ac.uk/software/tracer/.

55. Ronquist F, Teslenko M, van der Mark P, Ayres DL, Darling A, Höhna S, Larget B, Liu L, Suchard MA, Huelsenbeck JP. 2012. MrBayes 3.2: efficient Bayesian phylogenetic inference and model choice across a large model space. Systematic Biology, $61,539-542$

56. Roubal FR, Armitage J, Rohde K. 1983. Taxonomy of Metazoan ectoparasites of snapper, Chrysophrys autratus (Family Sparidae), from southern Australia, eastern Australia and New Zealand. Australian Journal of Zoology Supplementary Series, 31, 1-68.

57. Scott T. 1911. Notes on some trematode parasites of fishes. Report of the Fishery Board of Scotland, 28, 68-72.

58. Šimková A, Morand S, Jobet E, Gelnar M, Verneau O. 2004. Molecular phylogeny of congeneric monogenean parasites (Dactylogyrus): a case of intrahost speciation. Evolution, 58, 1001-1018

59. Šimková A, Matějusová I, Cunningham CO. 2006. A molecular phylogeny of the Dactylogyridae sensu Kritsky \& Boeger (1989) (Monogenea) based on the D1-D3 domains of large subunit rDNA. Parasitology, 132, 43-53.

60. Šimková A, Benovics M, Rahmouni I, Vukič J. 2017. Hostspecific Dactylogyrus parasites revealing new insights on the historical biogeography of Northwest African and Iberian cyprinid fish. Parasites \& Vectors, 10, 589.

61. Suriano DM, Incorvaia IS. 1995. Ancyrocephalid (Monogenea) parasites from siluriform fishes from the Paranean-Platean ichthyogeographical province in Argentina. Acta Parasitologica, 40, 113-124.

62. Talavera G, Castresana J. 2007. Improvement of phylogenies after removing divergent and ambiguously aligned blocks from protein sequence alignments. Systematic Biology, 56, 564-577.

63. Thompson JD, Higgins DG, Gibson TJ. 1994. CLUSTAL W: improving the sensitivity of progressive multiple sequence alignment through sequence weighting, position-specific gap penalties and weight matrix choice. Nucleic Acids Research, 22, $4673-4680$

64. Thompson AW, Betancur RR, López-Fernández H, Ortí G. 2014. A time-calibrated, multi-locus phylogeny of piranhas and pacus (Characiformes: Serrasalmidae) and a comparison of species tree methods. Molecular Phylogenetics and Evolution, 81, 242-257.

65. Van Every LR, Kritsky DC. 1992. Neotropical Monogenoidea. 18. Anacanthorus Mizelle and Price, 1965 (Dactylogyridae, Anacanthorinae) of piranha (Characoidea, Serrasalmidae) from the central Amazon, their phylogeny, and aspects of hostparasite coevolution. Journal of the Helminthological Society of Washington, 59, 52-75.

66. Verma J, Agrawal N, Verma AK. 2017. The use of large and small subunits of ribosomal DNA in evaluating phylogenetic relationships between species of Cornudiscoides Kulkarni, 1969 (Monogenoidea: Dactylogyridae) from India. Journal of Helminthology, 91, 206-214.

67. Wagener GR. 1857. Beiträge zur Entwicklungs-Geschichte der Eingeweidewürmer. Natuurkundige Verhandelingen van de Hollandsche Maatschappij der Wetenschappen te. Haarlem, 2, 1-I, 12.

68. Yamaguti S. 1937. Studies on the helminth fauna of Japan. Part 19. Fourteen new ectoparasitic trematodes of fishes. Japan: Kyoto University. 
69. Yamaguti S. 1953. Parasitic worms mainly from Celebes. Part 2. Monogenetic trematodes of fishes. Acta Medicinae Okayama, $8,203-265$.

70. Yamaguti S. 1968. Monogenetic trematodes of Hawaian fishes. Honolulu: University of Hawaii Press.

71. Yin W, Sproston NG. 1948. Studies on the monogenetic trematodes of China, Parts 1-5. Sinensia, 19, 57-85.

72. Young PC. 1967. A taxonomic revision of the subfamilies Monocotylinae Gamble, 1896 and Dendromonocotylinae
Hargis, 1955 (Monogenoidea: Monocotylidae). Journal of Zoology, 153, 381-422.

73. Zandt FK. 1924. Fischparasiten des Bodensees. Centralblatt für Bakteriologie und Parasitenkunde, I, Abteilung Originale, 92, 225-277.

74. Zietara MS, Lumme J. 2002. Speciation by host switch and adaptive radiation in a fish parasite genus Gyrodactylus (Monogenea, Gyrodactylidae). Evolution, 56, 2445-2458.

Cite this article as: Moreira J, Luque JL \& Šimková A. 2019. The phylogenetic position of Anacanthorus (Monogenea, Dactylogyridae) parasitizing Brazilian serrasalmids (Characiformes). Parasite 26, 44.

\section{(0) PARASTE}

An international open-access, peer-reviewed, online journal publishing high quality papers on all aspects of human and animal parasitology

Reviews, articles and short notes may be submitted. Fields include, but are not limited to: general, medical and veterinary parasitology; morphology, including ultrastructure; parasite systematics, including entomology, acarology, helminthology and protistology, and molecular analyses; molecular biology and biochemistry; immunology of parasitic diseases; host-parasite relationships; ecology and life history of parasites; epidemiology; therapeutics; new diagnostic tools.

All papers in Parasite are published in English. Manuscripts should have a broad interest and must not have been published or submitted elsewhere. No limit is imposed on the length of manuscripts.

Parasite (open-access) continues Parasite (print and online editions, 1994-2012) and Annales de Parasitologie Humaine et Comparée (1923-1993) and is the official journal of the Société Française de Parasitologie. 